such as the north-west of Britain. Nevertheless, since those at risk are mainly the elderly it should be possible, with the attention of doctors as well as families, to improve their "microenvironment" by giving them warm clothing and adequate domestic heating. ${ }^{2}$ In a caring society few should be entirely lacking in comfort and joy at this time of the year.

${ }^{1}$ Dudley EF, Beldin RA, Johnson BC. Climate, water hardness and coronary heart disease. 7 Chronic Dis 1969;22:25-48.

2 West RR, Lowe CR. Mortality from ischaemic heart disease-inter-town variation and its association with climate in England and Wales. Int ₹ Epidemiol 1976;5:195-201.

${ }^{3}$ Bainton D, Moore F, Sweetnam P. Temperature and deaths from ischaemic heart disease. Br F Prev Soc Med 1977;31:49-53.

4 Anon. Deadly cold. Br Med $\mathcal{F} 1963 ; \mathrm{i}: 203-4$.

${ }^{5}$ Monty CP. Victims of the cold. Lancet $1963 ; \mathrm{i}: 1048-9$

6 Anon. Mortality in cold winters. Br Med $\mathcal{F} 1963 ; \mathrm{i}: 347-8$.

${ }^{7}$ Macfarlane A. Daily deaths in Greater London. In: Office of Population Censuses and Surveys. Population Trends 5. London:HMSO, 1976:20-5.

\section{How necessary are elimination diets in childhood?}

When most babies were breast-fed ailments in the newborn were commonly attributed to the thinness, inadequacy, or disagreeable qualities of the milk and the infant was changed to cows' milk preparations. Now that most babies are bottlefed, cows' milk has become the culprit and is blamed for eczema, asthma, behaviour disorders, and constipation. In fact, the only disorders that have been proved to be due to cows' milk are bleeding from the gut ${ }^{1}$ and chronic diarrhoea. Yet at times the outcry-even by well-established paediatricianshas become so emotional that before long, no doubt, demands will be heard that dried milks should be labelled "this preparation may harm your health."

As the questions and warnings about the real and imagined dangers of cows' milk have spread from doctors to the public, many mothers have looked for alternatives. About one-third of the infants receiving bottle feeds in the United States have a milk substitute based on soya bean protein. In Britain these preparations cost about five times more than cows' milk preparations. The results of short-term studies have suggested that growth of infants fed on soya protein is similar to that of babies reared on cows' or breast milk. The results of long-term studies of growth and intellect are not yet available, nor are there yet reliable estimates of the number of infants who react adversely to the new preparations.

The second effect of the widespread belief that cows' milk may explain almost any symptom in an infant has been some uncontrolled enthusiasm among paediatricians for the use of "elimination diets." For example, Atherton and colleagues have recently reported a dramatic success for a milk-free, eggfree diet in some children with infantile eczema. ${ }^{2}$ Fortunately publicity is being given to the risks as well as the merits of dietary modification: the potential hazards of fashionable macrobiotic diets were reviewed in a $B M \mathcal{F}$ article last year. ${ }^{3}$ Another study showed how elimination diets can result in inadequate caloric intake and failure to thrive. ${ }^{4}$ Gluten-free diets had been prescribed for large numbers of children without a specific diagnosis being made; detailed investigation showed that most did not have a serious underlying disorder and did not require a diet at all.

The value of elimination diets has been documented best in coeliac disease and intolerance to cows' milk protein. Infants less than a year of age with chronic diarrhoea need systematic investigation. Examination of the stool for a pathogenic Escherichia coli and giardia can be performed as a preliminary test in the outpatient clinic. Next a full blood count, a sucrose and lactose tolerance test, and a sweat test should be arranged, and finally a jejunal biopsy. There are no agreed diagnostic criteria for cows' milk protein intolerance, but the diagnosis is reasonably certain if symptoms recur on three challenges, ${ }^{5}$ or if changes can be shown in the villi on microscopy of biopsy specimens before and after a challenge, ${ }^{6}$ or changes in IgM plasma cells in the mucosa after a challenge. ${ }^{7}$ If an elimination diet is prescribed it should be supervised by both a paediatrician and a dietitian, since how long the diet is needed cannot be assessed when it is first prescribed-regular challenges are necessary to determine how long dietary restriction must be continued. A rigid diet may be unpalatable and lead to deficient intake of calories.

The confusion that may be produced by uncontrolled prescription of elimination diets has been highlighted by the results of uncritical prescription of gluten-free diets (without a prior small intestinal biopsy) for children suspected of having coeliac disease. This approach is rare in Britain but apparently is still common in the United States, ${ }^{4}$ despite the diagnostic confusion which may arise with the need for later reinvestigation to determine whether permanent gluten intolerance exists. ${ }^{8}$ Perhaps a larger problem, in both Britain and the United States, is the unnecessary prescription of elimination diets for non-specific chronic diarrhoea, variously known as the peas/carrots syndrome, toddler's diarrhoea, and the irritable colon syndrome of infancy, in children over 1 year who are growing normally. Apart from examining the stool for pathogens and parasites no investigations are required and no treatment is needed provided the infant is growing normally-as shown by progress on growth charts. These children grow out of their symptoms by the age of 3 or 4 years. Most often, probably, the condition has some benign basis such as failure to chew properly-foods such as beans are characteristically seen in the stools. We have no evidence that removing some foods from the diet is of any real value in this self-limiting syndrome.

1 Wilson JF, Lahey ME, Heiner DC. Studies on iron metabolism. V. Further observations on cow's milk-induced gastrointestinal bleeding in infants with iron-deficiency anaemia. $\mathcal{F}$ Pediatr $1974 ; 84: 335-44$.

${ }^{2}$ Atherton DJ, Sewell M, Soothill JF, Wells RS. A double-blind controlled crossover trial of an antigen-avoidance diet in atopic eczema. Lancet $1978 ; \mathrm{i}: 401-3$.

${ }^{3}$ Roberts IF, West RJ, Ogilvie D, Dillon MJ. Malnutrition in infants receiving cult diets: a form of child abuse. Br Med f 1979;i:296-8.

${ }^{4}$ Lloyd-Still JD. Chronic diarrhoea of childhood and the misuse of elimination diets. F Pediatr 1979;95:10-3.

${ }^{5}$ Goldman AS, Anderson DW, Sellers WA. Milk allergy. 1. Oral challenge with milk and isolated milk proteins in allergic children. Pediatrics $1963 ; 32: 425-43$.

${ }^{6}$ Kuitunen P, Rapola J, Savilanti E, et al. Response of the jejunal mucosa to cow's milk in the malabsorption syndrome with cow's milk intolerance. A light- and electron-microscopic study. Acta Paediatr Scand 1973;62: 585-95

7 Shiner M, Ballard J, Smith ME. The small-intestinal mucosa in cow's milk allergy. Lancet $1975 ;$ i:136-40.

${ }^{8}$ Walker-Smith JA, Kilby A, France NE. In: McNicholl B, McCarthy $\mathrm{CF}$, Fottrell PF, eds. Perspectives in coeliac disease, proceedings of the third international coeliac symposium, Galway. Lancaster: MTP Press, 1978:267. 